\title{
First record of the nudibranch Marionia blainvillea (Risso, 1818) (Gastropoda: Heterobranchia) for Montenegro
}

\author{
Vesna MAČIĆ*1, Milica JOVANOVIĆ ${ }^{1}$, Domen TRKOV² and Lovrenc LIPEJ² \\ ${ }^{1}$ University of Montenegro, Institute of Marine Biology, Dobrota bb, 85330 Kotor, Montenegro \\ ${ }^{2}$ Marine Biology Station, National Institute of Biology, Fornače 41, 6330 Piran, Slovenia \\ *Corresponding author, e-mail: macic.v@ac.me
}

\begin{abstract}
One specimen belonging to the nudibranch Marionia blainvillea (Risso, 1818) was found crawling on the gorgonian Leptogorgia sarmentosa (Esper, 1789) at Sv. Nedjelja, Boka Kotorska Bay, Montenegro. This is the first record of the species for Montenegrin waters and the third for the Adriatic Sea.
\end{abstract}

Key words: Marionia blainvillea, seaslug, coralligenous assemblage, Boka Kotorska, Montenegro

\section{INTRODUCTION}

Recently, an updated checklist of the Adriatic opisthobranch fauna was published (ZENETOS et al., 2016), which represents the most comprehensive overview of sea slug fauna in the Adriatic Sea with a total of 223 species recorded. However, after that review, several new records of Adriatic sea slugs were published (e.g. FURFARO et al., 2016; GEROVASILEIOU et al., 2017; TRKOV et al., 2017).

The knowledge of marine molluscs in Montenegro is far from being complete and the published literature is still very scarce. Recently, an annotated review of molluscs species recorded for Montenegro was written by PETOVIĆ et al. (2017). Among 354 molluscs listed, 198 are gastropods with 49 of them being opisthobranchs.

During a SCUBA inventory sampling in the area of Sv. Nedjelja in Boka Kotorska Bay, a nudibranch Marionia blainvillea (Risso, 1818) was found. The aim of this contribution is to present data on the finding of this species, which was previously not reported nor in the checklist of Montenegrin molluscs (PETOVIĆ et al. 2017), neither in the review of Adriatic opisthobranchs by ZENETOS et al. (2016).

\section{MATERIAL AND METHODS}

During a SCUBA survey of Mediterranean stony coral colonies (Cladocora caespitosa Linnaeus 1767) at the locality of Sv. Nedjelja (4227'28.92'N, 1840'31.64E”); close to Herceg Novi, Boka Kotorska (Fig. 1), at $24^{\text {th }}$ August 2017, a small nudibranch was found creeping on the gorgonian Leptogorgia sarmentosa (Esper, $1789)$ at $26 \mathrm{~m}$ depth in the coralligenous biocoenosis (Fig. 2A). The specimen was collected and stored at the laboratory of the Institute of Marine Biology in Kotor, where it was photographed by stereomicroscope Nikon SMZ800 
and analysed for species identification. (BALLESTEROS et al., 2012-2018).

\section{RESULTS AND DISCUSSION}

The recorded specimen was a juvenile with a semi-transparent pale yellowish body, rectangular in shape (Fig. 2B). The back and flanks are covered by bumps, outlined with pale line that create a network over the body. The specimen alive measured $5 \mathrm{~mm}$ in length. The oral veil was bilobed and with many digit-like projections. Generally, on the flanks of the notum from 10 to 12 ramified appendixes of unequal size were present.

Up to date the species was recorded in the Mediterranean Sea, mainly in its western portion such as the Gulf of Naples (SCHMEKEL \& PORTMANN, 1982) central Tyrrhenian Sea (FURFARO \& MARIOTTINI 2016), North-East Sardinia (TRAINITO \& DONEDDU, 2015) and the Spanish Mediterranean coast and Balearic Islands (BALLESTEROS et al., 2012-2018). Outside the Mediterranean waters it was reported for Madeira, Canary Islands, Azores, Angola and recently for the Monte Hermoso (Argentina) (CERVERA et al., 2004; BALLESTEROS et al., 2012-2018).

The Tritoniidae is a very specialized family with species showing a strong relationship with gorgonians and soft corals, on which they feed, mate and live (FURFARO et al., 2017). Because of that it is curious that M. blainvillea was recorded

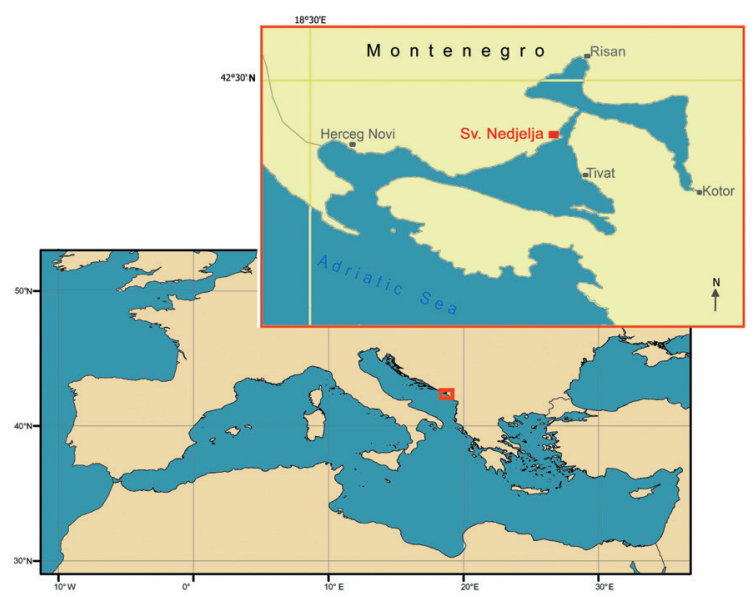

Fig.1. Location of the site Sv. Nedjelja (Boka Kotorska Bay) where the specimen of $\mathrm{M}$. blainvillea was found.

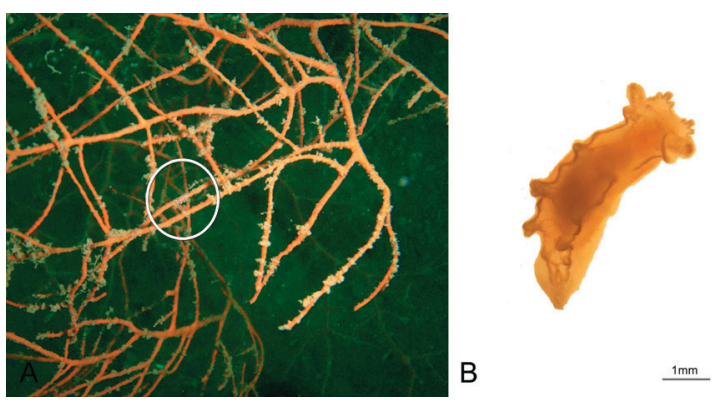

Fig. 2. A) White circle indicates the M. blainvillea specimen on the gorgonian L. sarmentosa, B) M. blainvillea individual

as one among the dominant opisthobranch in the samples $(>30 \%)$ of the non-commercial fraction of the trawling fishery in waters off Catalan coast in front of Blanes where bottom types are sand and mud (only one trawling area has sand and stones) (DOMĖNECH et al., 2006). In the Boka Kotorska Bay the specimen was found on the gorgonian Leptogorgia sarmentosa Esper, 1789, which was reported as their food together with a variety of other octocoral prey (BARLETTA \& MELONE, 1976; BARLETTA, 1981; MCDONALD \& NYBAKKEN, 1999). In the inner part of the Boka Kotorska Bay there are few locations, about $2 \%$ of the Kotor-Risan bay (RAC/ SPA - UNEP/MAP, 2013), characterized by coralligenous assemblages where the dominant species are Cladocora caespitosa (Linneaus, 1767), Savalia savaglia (Bertoloni, 1819), Leptogorgia sarmentosa (Esper, 1789), Parazoanthus axinellae (Schmidt, 1862), Axinella cannabina (Esper, 1794) The Sv. Nedjelja site, on the end of Verige strait, is one of only two other, rather small similar assemblages in the outer part of the Boka Kotorska Bay (Tivat-Herceg Novi Bay).

The finding of $M$. blainvillea represents the first record of this species in the Montenegrin part of the Adriatic Sea and the third record of this species in the Adriatic Sea. Previously, this species was recorded by J. Prkić in Kosirina at the Murter Island (Croatia) in the Middle Adriatic Sea and at Rimini (Italy) in the North Adriatic Sea (BALLESTEROS et al., 2012-2018). Since juveniles are rather well camouflaged on the gorgonians, as pointed out for the related species Tritonia nilsodhneri (Marcus Ev., 1983), which was recently discovered in Boka Kotorska Bay 
(FURFARO et al., 2017), it could be supposed that $M$. blainvillea is much more common in the Adriatic Sea than what is known. Adult specimens are, on the other hand, generally found hidden under the stones. These habits, but also the relatively small availability of appropriate habitat of the $M$. blainvillea are probably the main reasons why the species was previously not mentioned in the recently published review of the Adriatic opisthobranch fauna by ZENETOS et al. (2016).

\section{AKNOWLEDGEMENTS}

We would like to thank Ministry of Science Montenegro and Slovenian Research Agency for financial support of the bilateral project. Authors also would like to thank anonymous referees for their kind help in improving the manuscript
BALLESTEROS, M.., E. MADRENAS \& M. PONTES. 2012-2018. "Marionia blainvillea" in OPKOpisthobranquis. Published 16/05/2012, Accessed 11/01/2018 at https://opistobranquis. info/en/kGuVf.

BARLETTA, G. \& G. MELONE. 1976. Nudibranchi del Promontorio di Portofino (Genova) (Gastropoda Nudibranchia). Natura, Società Italiana di Scienze Naturali, Milano, 67(3-4): 203-236.

BARLETTA, G. 1981. Gasteropodi nudi (Pleurobranchomorpha, Sacoglossa, Aplysiomorpha e Nudibranchia) [Consiglio Nazionale delle Richerche, Guide per il riconoscimento delle specie animali delle acque lagunari e costiere italiane $\mathrm{AQ} / 1 / 92,3]$. Quaderni della Civica Stazione Idrobiologica di Milano, 9:1-124.

CERVERA, J.L., G. CALADO, C. GAVAIA, M.A.E. MALAQUIAS, J. TEMPLADO, M. BALLESTEROS, J.C. GARCÍA-GÓMEZ \& C. MEGINA. 2004. An annotated and updated checklist of the opisthobranchs (Mollusca: Gastropoda) from Spain and Portugal (including islands and archipelagos). Boletín Instituto Español de Oceanografía, 20 (1-4): 1-122.

DOMÈNECH, A., C. AVILA \& M. BALLESTEROS. 2006. Opisthobranch molluses from the subtidal trawling grounds of Blanes (Girona, north-east Spain). J. Mar. Biol. Ass. U.K., 86: 383-389.

FURFARO, G., \& MARIOTTINI, P. 2016. Check-list of the Nudibranchs (Mollusca Gastropoda) from the biodiversity hot spot "Scoglio del Corallo" (Argentario promontory, Tuscany). Biodiversity Journal, 7(1): 67-78.
FURFARO, G., E. TRAINITO, F. DE LORENZI, M. FANTIN \& M. DONEDDU. 2017. Tritonia nilsodhneri Marcus Ev., 1983 (Gastropoda, Heterobranchia, Tritoniidae): first records for the Adriatic Sea and new data on ecology and distribution of Mediterranean populations. Acta Adriat., 58(2): 261- 270.

GEROVASILEIOU, V., E.H.KH. AKEL, O. AKYOL, G. ALONGI, F. AZEVEDO, N. BABALI, R. BAKIU, M. BARICHE, A. BENNOUI, L. CASTRIOTA, C.C. CHINTIROGLOU, F. CROCETTA, A. DEIDUN, S. GALINOU-MITSOUDI, I. GIOVOS, M. GÖKOĞLU, A. GOLEMAJ, L. HADJIOANNOU, J. HARTINGEROVA, G. INSACCO, S. KATSANEVAKIS, P. KLEITOU, J. KORUN, L. LIPEJ, M. MALEGUE, N. MICHAILIDIS, A. MOUZAI TIFOURA, P. OVALIS, S. PETOVIĆ, S. PIRAINO, S.I. RIZKALLA, M. ROUSOU, I. SAVVA, H. ŞEN, A. SPINELLI, K.G. VOUGIOUKALOU, E. XHARAHI, B. ZAVA \& A. ZENETOS. 2017. New Mediterranean Biodiversity Records (July 2017). Medit. Mar. Sci., 18(2): 355-384.

MCDONALD, G. R. \& J. W. NYBAKKEN. 1999. A worldwide review of the food of nudibranch mollusks. II. The suborder Dendronotacea. Veliger, 42(1): 62-66.

PETOVIĆ, S., S. GVOZDENOVIĆ \& Z. IKICA. 2017. An annotated checklist of the marine molluscs of the South Adriatic Sea (Montenegro) and a comparison with those of neighboring areas. Turkish Journal of Fisheries and Aquatic Sciences, 17: 921-934.

RAC/SPA - UNEP/MAP. 2013. Ecological quantitative description of Boka Kotorska Bay marine area Montenegro). By Golder Associ- 
ates. Editors. RAC/SPA - MedMPAnet Project, Tunis.

SCHMEKEL, R. L., \& A. PORTMANN. 1982. Opisthobranchia des Mittelmeeres, Nudibranchia und Saccoglossa. Fauna e flora del Golfo di Napoli 40, Monografia della Stazione Zoologica di Napoli, Springer-Verlag, pp. 1-410. TRAINITO, E., \& DONEDDU, M. 2015. Contribution to the knowledge of the molluscan fauna in the Marine Protected Area Tavolara-Punta Coda Cavallo: Ordo Nudibranchia. Bollettino Malacologico, 51: 54-70.
TRKOV, D., B. MAVRIČ \& L. LIPEJ. 2017. Alien Seaslugs (Gastropoda: Heterobranchia) in harbors and marinas of Slovenia. In Ramšak, A. et al. (Ed.): Proceedings of $52^{\text {nd }}$ European Marine Biology Symposium, Portorož, Slovenia, 25 - 29 September 2017.

ZENETOS, A., V. MAČIĆ, A. JAKLIN, L. LIPEJ, D. POURSANIDIS, R. CATTANEO-VIETTI, S. BEQIRAJ, F. BETTI, D. POLONIATO, L. KASHTA, S. KATSANEVAKIS, \& F. CROCETTA. 2016. Adriatic 'opisthobranchs' (Gastropoda, Heterobranchia): shedding light on biodiversity issues. Marine Ecology, 37 (6):1239-1255.

Received: 9 March 2018

Accepted: 16 May 2018

\title{
Prvi nalaz puža golaća Marionia blainvillea (Risso, 1818) (Gastropoda: Heterobranchia) u Crnoj Gori
}

\author{
Vesna MAČIĆ**, Milica JOVANOVIĆ, Domen TRKOV i Lovrenc LIPEJ \\ *e-pošta:macic.v@ac.me
}

\section{SAŽETAK}

Jedan primjerak puža golaća Marionia blainvillea (Risso, 1818) nađen je da puzi na gorgoniji Leptogorgia sarmentosa (Esper, 1789) na lokaciji Sv. Nedjelja, Bokokotorski zaliv, Crna Gora. Ovo je prvi nalaz te vrste za Crnu Goru i treći za Jadransko more. Gora

Ključne riječi: Marionia blainvillea, puž golać, koraligenska zajednica, Boka Kotorska, Crna 